\title{
On the occurrence and ecology of Glaucus atlanticus Forster, 1777 (Mollusca: Nudibranchia) along the Southwestern Atlantic coast
}

\author{
RAPHAEL M. PINOTTI ${ }^{1}$, FABIO C. BOM ${ }^{1}$ and ERIK MUXAGATA ${ }^{2}$ \\ ${ }^{1}$ Laboratório de Ecologia de Invertebrados Bentônicos, Instituto de Oceanografia, Universidade Federal \\ do Rio Grande/FURG, Av. Itália, Km 8, Campus Carreiros, 96203-900 Rio Grande, RS, Brazil \\ ${ }^{2}$ Laboratório de Ecologia do Zooplâncton, Instituto de Oceanografia, Universidade Federal do Rio \\ Grande/FURG, Av. Itália, Km 8, Campus Carreiros, 96203-900, Rio Grande, RS, Brazil \\ Manuscript received on February 15, 2018; accepted for publication on June 21, 2018
}

\begin{abstract}
How to cite: PINOTTI RM, BOM FC AND MUXAGATA E. 2019. On the occurrence and ecology of Glaucus atlanticus Forster, 1777 (Mollusca: Nudibranchia) along the Southwestern Atlantic coast. An Acad Bras Cienc 91: e20180154. DOI 10.1590/0001-3765201920180154.

Abstract: Unlike the majority of the nudibranchs, Glaucidae lives adrift at the sea surface within Tropical and Subtropical ocean basins, feeding on cnidarians or using them to attach their egg strings as a reproductive strategy. The latitudinal distribution of Glaucus atlanticus throughout the Brazilian Province is influenced by the Brazil current and, in its austral limit, by seasonal shifts in the Subtropical Convergence Zone (especially under the influence of ENSO El Niño events). Once over the shelf, seasonal wind patterns and meteorological events can force a passive displacement of the species towards the shore. Such onshore displacements may result on strandings of Glaucus spp. and other pleustonic species of the "blue plankton" community, like already reported worldwide and recently at the Southern Brazilian / Uruguayan coasts. Although fascinating, Glaucus spp. should be considered harmful to humans and people should thus avoid direct contact; if this accidentally occurs, short-term treatments can be implemented besides looking for medical attention. The current geographical distribution of Glaucus atlanticus over the Brazilian coast reveals some inaccuracy and gaps; the present study not only revises the ecology of this species but also evidences the occurrence of summer strandings and its austral distribution into subtropical shores.
\end{abstract}

Key words: biogeography, cnidarians, holoplankton, nudibranch, strandings.

Nudibranchs (commonly known as sea slugs) form the most diverse order of opistobranch gastropods and are easily recognized by the soft and elongated shell-less body, with the majority of the species within this order being epibenthic crawlers. More than 3,000 species are worldwide described (Wägele and Klussmann-Kolb 2005) and

Correspondence to: Raphael Mathias Pinotti

E-mail:pinottirm@gmail.com

ORCiD: http://orcid.org/0000-0002-2281-8618 around 100 species have already been reported in the Brazilian coast (da Costa et al. 2010).

Ecological changes in cold and temperate waters may act as biogeographical barriers controlling the dispersion of species (Naranjo et al. 1998, García and Bertsch 2009) especially for tropical nudibranchs. Such cold-water barrier can play a significant role for the lowest diversity of opistobranchs within the Southern Brazilian Shelf (García et al. 2006) due to its proximity to the Subtropical Convergence Zone (Garcia 1997) 
and the Southwest Atlantic Shelves Province (sensu Longhurst 2006), in which eurythermal and euryhaline species generally occurs (Boschi 2000).

Coastal reefs and rocky shores can also contribute for the occurrence of relatively high diversity of bottom-dwelling nudibranchs along the Tropical Southwest Atlantic - particularly within the Southern Brazilian Bight - and a decreasing diversity towards the Subtropical Southern Brazilian Shelf (García et al. 2006). Such lower diversity may be attributed to morphology changes on the coastal plain - from the Rio Grande do Sul state $(\approx$ $\left.29^{\circ} \mathrm{S}\right)$ to the northeastern Uruguayan coast $\left(\approx 34^{\circ}\right.$ S) - in which rocky shores are replaced by sandy shores, environments recognized as unfavorable for benthic nudibranch species (Franz 1970). A different story can be told to those species adapted to the pelagic realm: only few nudibranchs are truly holoplanktonic, displaying complete life cycles in the water column, like the pleustonic species of the family Glaucidae that are usually found floating at the sea surface (Lalli and Gilmer 1989) and thus not influenced by bottom composition and its morphology.

Due to morphological and anatomical synapomorphies, Glaucus was previously reported as the single valid genus inside the Glaucidae family, with only two valid species: Glaucus atlanticus Forster, 1977, which presents a cosmopolitan Tropical / Subtropical distribution; and G. marginatus (Reinhardt \& Bergh, 1864) (previously recorded as Glaucilla marginata), more restricted to the Indian and Pacific Oceans (Valdés and Campillo 2004). A recent molecular and phylogenetic approach revealed distinct cryptic species within the informal clade 'marginatus', raising up to five the number of valid species within Glaucus (Churchill et al. 2014a): G. bennettae limited to the South Pacific Ocean and $G$. thompsoni and G. mcfarlanei restricted to the North Pacific Ocean. Another DNA study on G. atlanticus suggests that the species appear to be panmictic within ocean basins but not globally, given the presence of geological barriers (continents) and the low water temperatures of Arctic / Southern Oceans (Churchill et al. 2014b).

Displaying a carnivorous (and rarely cannibalistic) behavior, Glaucus species usually preys on pleustonic cnidarians like the by-thewind sailor Velella velella (Linnaeus, 1758), the blue-button Porpita porpita (Linnaeus, 1758) and the Portuguese man-o'-war Physalia physalis (Linnaeus, 1758) (Bieri 1966, Thompson and Bennett 1970, McDonald 2014). When feeding, Glaucus use their jaws and the radular teeth to grab and tear the soft tissues and tentacles of these cnidarians (Lalli and Gilmer 1989). As a reproductive strategy, $G$. atlanticus can further use uneaten parts of their prey (e.g., Velella in Gliesch 1930) and even the bubble raft of the violet-sea-snail Janthina spp. Röding, 1798 (Laursen 1953 apud Lalli and Gilmer 1989) to attach their egg strings. Unfortunately, there is no sufficient data about the reproduction and development of Glaucus spp. in nature, except under laboratory conditions (Ross and Quetin 1990).

The distribution of $G$. atlanticus throughout the Western Atlantic Ocean is highly associated with the gyre systems in both hemispheres and limited by the (warm) water temperature: (i) within the Caribbean Province, up to Bermuda Islands and (ii) within the Brazilian Province, up to Brazil/ Uruguay border (García et al. 2006, Padula et al. 2012). The Subtropical Convergence Zone, where Brazil Current (warm, weak and oligotrophic) and Malvinas Current (cold, strong and nutrientrich) converge is the most relevant oceanographic feature of the Southwestern Atlantic (Garcia 1997), reaching higher latitudes during the austral summer (Maamaatuaiahutapu et al. 1994, Barré et al. 2006) and especially under the influence of ENSO El Niño events (Ortega and Martínez 2007). The seasonal migration of the Convergence Zone modify the characteristics of water masses over the Southern 
Brazilian / Uruguayan shelf, with a predominance of Tropical and Subtropical Waters along the summer-autumn seasons (Lima et al. 1996, Garcia 1997, Ortega and Martínez 2007), which thus can be responsible for the distribution of $G$. atlanticus bounded to this water mass.

The intrusion of Coastal and Tropical Waters over the Southern Brazilian / Uruguayan shelf during summer (Ortega and Martínez 2007) favors the passive displacement of the species towards the shore, a movement largely influenced by the seasonal wind patterns and strong S-SW winds related with frontal systems and cyclonic events (Marone and Camargo 1994, Krusche et al. 2002). Such onshore displacements of Glaucus spp. may result on strandings like those already reported on Brazil (Gliesch 1930, Vannucci 1939, Rios 2009), South Africa (Macnae 1954), India (Srinivasulu et al. 2012), Australia (Iredale 1940,
Bennett 1966, Thompson and Bennett 1970), El Salvador (Segovia and López 2015) and Costa Rica (García-Méndez and Camacho-García 2016). Other pleustonic species of the "blue plankton" community are frequently associated with Glaucus spp. strandings (Gliesch 1930, Vannucci 1939, Bieri 1966, González et al. 2014, Segovia and López 2015).

Massive strandings of the blue dragon $G$. atlanticus were registered along the Southwestern Atlantic Ocean coast during the summers of 2011 and 2017 (Figure 1). In 2011, scattered strandings of G. atlanticus and large quantities of the pleustonic species $V$. velella, $P$. porpita, $P$. physalis and Janthina spp. were recorded from Cassino Beach Southern Brazil to La Paloma - Uruguay $(\approx 350 \mathrm{~km}$ of distance) after the passage of two consecutive cold fronts associated with a cyclonic event. Another stranding phenomenon was recorded in

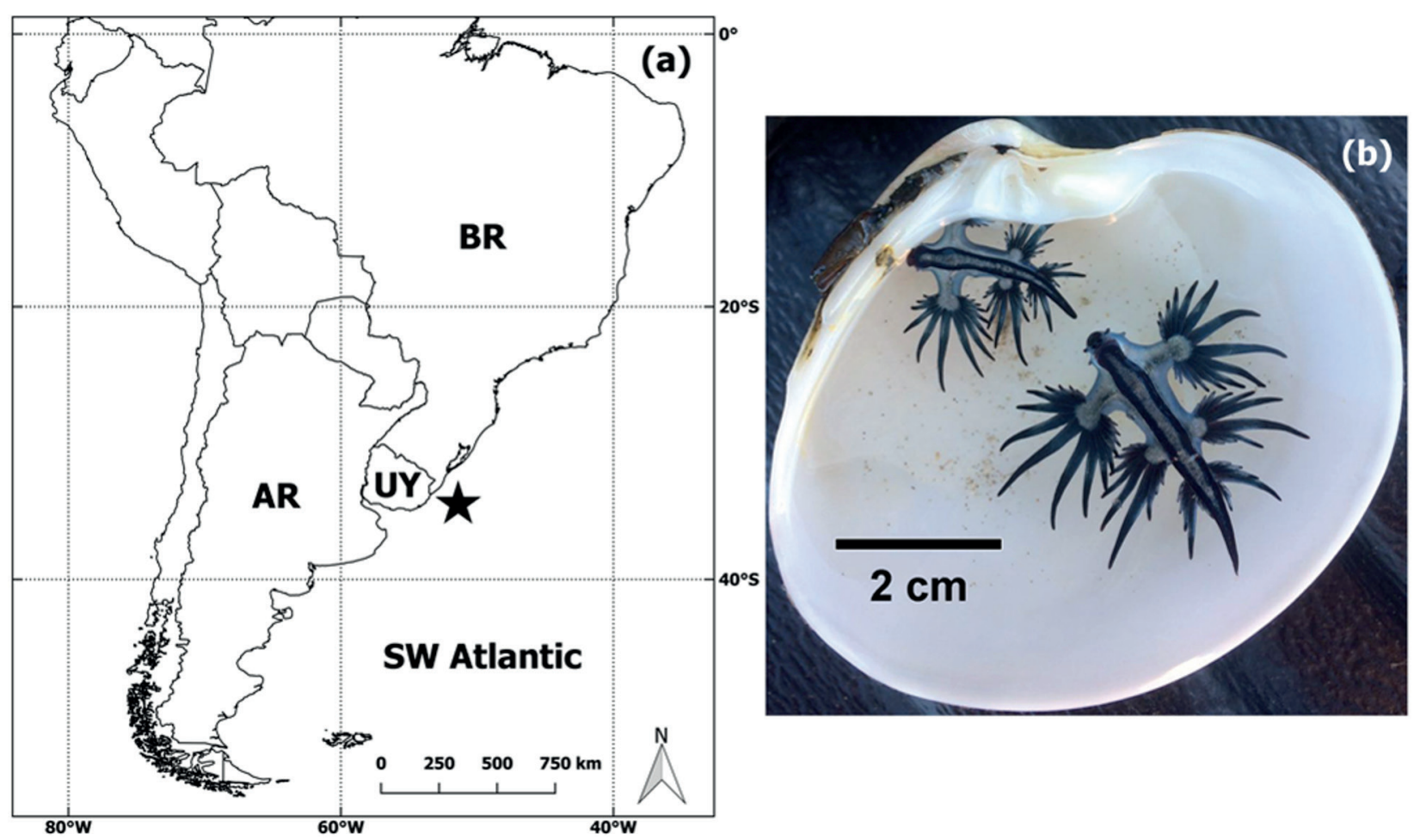

Figure 1 - Brazilian (BR), Uruguayan (UY) and Argentinean (AR) shores, evidencing the area in which Glaucus atlanticus was reported during the summers of 2011 and 2017 (a). During the 2017' strandings, G. atlanticus (b) and several cnidarians were found scattered within the upper intertidal at Cassino Beach $\left(32.174^{\circ} \mathrm{S} ; 52.134^{\circ} \mathrm{W}\right)$. 
2017 from Cassino Beach to Concheiros Beach, both in Southern Brazil $(\approx 200 \mathrm{~km}$ of distance $)$ two days after a storm (moderate SW winds of $4.4 \mathrm{~ms}^{-1}$ on average; wind gusts up to $13.7 \mathrm{~ms}^{-1}$; oceanic wave heights up to $3 \mathrm{~m}$ ). During this later stranding event, G. atlanticus specimens (15 - 35 $\mathrm{mm} ; 20$ individuals per running meter) were found scattered within the upper intertidal, among large quantities of $V$. velella and a few Janthina spp.

Although fascinating to regular tourists which swarm the beaches (especially during the summer season) or even artistic inspiring to the young generations (Cavallari 2015), Glaucus spp. should be considered as harmful to humans as their prey. Given their soft body and the absence of a protective shell, Glaucus species use the ingestion of both fired and undischarged nematocysts of their prey as a defensive strategy, concentrating them inside cnidosacs located at the tip of each cerata (Thompson and Bennett 1970). Along the Southwestern Atlantic Ocean, G. atlanticus mainly feed on $V$. velella, $P$. porpita and $P$. physalis cnidarians. The nematocysts of those species may cause skin irritation (Johnson and Allen 2012) or even death when Physalia toxin is involved (Burnett and Gable 1989, Edmonds 1995).

Humans who have had contact with $G$. atlanticus that had feed on Physalia may present clinical issues similar to P. physalis envenomation (Thompson and Bennett 1969, Edmonds 1995, Williamson et al. 1996, Tibballs 2006) including nausea, pain, vomiting, acute allergic contact dermatitis, erythema, urticarial papules, potential vesicle formation and post-inflammatory hyperpigmentation (Ottuso 2009). People should thus avoid direct contact with Glaucus spp. as for any other wild animal but if this accidentally occurs, treatment of stings may include the use of potent topical steroids, cool compresses and antihistamine therapy (Ottuso 2009) besides seeking medical attention immediately.
The current geographical distribution of G. atlanticus in the Western South Atlantic reveals some inaccuracy and gaps in the species occurrence, given the reduced sampling efforts on nudibranchs towards the Southern Brazilian / Uruguayan Subtropical waters, which finally results in underestimated diversity (García et al. 2006). So far, the species distribution over the Brazilian coast has been reported from Alagoas state (Padula et al. 2012) to Rio Grande do Sul state (Gliesch 1930, Rios 1975, 2009) with the later essentially based on outdated literature with vague information. This study not only verifies the distribution of G. atlanticus into Uruguayan shores (La Paloma, Rocha: Figueiras and Sicardi 1980, Scarabino 2004) but also evidences the nowadays occurrence of massive strandings during summer (when issues related to public health may occur), raising the importance of studies on the species' ecology within its austral limit of distribution.

\section{AUTHOR CONTRIBUTIONS}

RMP and FCB wrote the manuscript with support from EM. 2011 data were provided by EM and 2017 by RMP and FCB. All authors discussed the results and contributed to the final version of the manuscript.

\section{REFERENCES}

BARRÉ N, PROVOST C AND SARACENO M. 2006. Spatial and temporal scales of the Brazil-Malvinas Current confluence documented by simultaneous MODIS Aqua $1.1-\mathrm{km}$ resolution SST and color images. Adv Space Res 37(4): 770-786.

BENNETT I. 1966. Some pelagic molluscs and associated animals in South-Eastern Australian waters. J Malacol Soc Aust 1(9): 40-51.

BIERI R. 1966. Feeding preferences and rates of the snail, Ianthina prolongata, the barnacle, Lepas anserifera, the nudibranchs, Glaucus atlanticus and Fiona pinnata, and the food web in the marine neuston. Publ Seto Mar Biol Lab 14(2): 161-170. 
BOSCHI EE. 2000. Species of Decapod Crustaceans and their distribution in the American marine zoogeographic provinces. Rev Invest Des Pesq 13: 7-136.

BURNETT JW AND GABLE WD. 1989. A fatal jellyfish envenomation by the Portuguese man-o'-war. Toxicon 27(7): 823-824.

CAVALLARI DC. 2015. Shells and bytes: mollusks in the 16bit era. J Geek Stud 2(1): 28-43.

CHURCHILL CKC, VALDÉS Á AND FOIGHIL DÓ. 2014a. Molecular and morphological systematics of neustonic nudibranchs (Mollusca: Gastropoda: Glaucidae: Glaucus), with descriptions of three new cryptic species. Invertebr Syst 28(2): 174-195.

CHURCHILL CKC, VALDÉS Á AND FOIGHIL DÓ. 2014b. Afro-Eurasia and the Americas present barriers to gene flow for the cosmopolitan neustonic nudibranch Glaucus atlanticus. Mar Biol 161(4): 899-910.

DA COSTA S, PADULA V AND SCHRÖDL M. 2010. A new species of Hypselodoris and a redescription of Hypselodoris picta lajensis (Nudibranchia: Chromodorididae) from Brazil. Veliger 51(1): 15-25.

EDMONDS C. 1995. Field guide for medical treatment - Dangerous marine creatures, 1st ed., Flagstaff: Best Publishing Company, 276 p.

FIGUEIRAS A AND SICARDI OE. 1980. Catálogo de los moluscos marinos del Uruguay. Parte X. Revisión actualizada de los moluscos marinos del Uruguay con descripción de las especies agregadas. Sección II Gastropoda y Cephalopoda. Com Soc Malac Uruguay 5(38): 243-244.

FRANZ DR. 1970. Zoogeography of Northwest Atlantic opisthobranch molluscs. Mar Biol 7(2): 171-180.

GARCIA CAE. 1997. Physical oceanography. In: Seeliger U et al. (Eds), Subtropical convergence environments: the coast and sea in the Southwestern Atlantic, Berlin: SpringerVerlag, p. 94-96.

GARCÍA FJ AND BERTSCH H. 2009. Diversity and distribution of the Gastropoda Opisthobranchia from the Atlantic Ocean: a global biogeographic approach. Sci Mar 73(1): 153-160.

GARCÍA FJ, DOMÍNGUEZ M AND TRONCOSO JS. 2006. Biogeographic considerations of the Opisthobranchia (Mollusca: Gastropoda) fauna from the Brazilian littoral and nearby areas. Bonn Zool Bull 55(3/4): 203-222.

GARCÍA-MÉNDEZ K AND CAMACHO-GARCÍA YE. 2016. New records of heterobranch sea slugs (Mollusca: Gastropoda) from Isla del Coco National Park, Costa Rica. Rev Biol Trop 64(1): 205-219.

GLIESCH R. 1930. Sobre dois molluscos pelagicos pouco conhecidos. Egatea 15: 379-382.

GONZÁLEZ S ET AL. 2014. Dosima fascicularis (Cirripedia: Lepadidae) in Uruguayan waters: the southernmost western Atlantic presence of the "blue goose barnacle". Mar Biodivers Rec 7(e99): 1-8.

IREDALE T. 1940. Glaucus, a mystery of the sea. Proc R Zool Soc New South Wales 1939/1940: 40-41.

JOHNSON WS AND ALLEN DM. 2012. Zooplankton of the Atlantic and Gulf coasts: a guide to their identification and ecology, 2nd ed., Baltimore: Johns Hopkins University Press, 472 p.

KRUSCHE N, SARAIVA JMB AND REBOITA MS. 2002. Normais climatológicas provisórias para 1991 a 2000 para Rio Grande, RS, 1st ed., Santa Maria: Imprensa Universitária, 84 p.

LALLI CM AND GILMER RW. 1989. Pelagic snails: the biology of holoplanktonic gastropod mollusks, 1st ed., Stanford: University Press, $276 \mathrm{p}$.

LIMA ID, GARCIA CAE AND MÖLLER OO. 1996. Ocean surface processes on the southern Brazilian shelf: characterization and seasonal variability. Cont Shelf Res 16(10): 1307-1317.

LONGHURST AR. 2006. Ecological geography of the sea, 2nd ed., San Diego: Elsevier Academic Press, 560 p.

MAAMAATUAIAHUTAPU K, GARÇON VC, PROVOST C, BOULAHDID M AND BIANCHI AA. 1994. Spring and winter water mass composition in the Brazil-Malvinas Confluence. J Mar Res 52: 397-426.

MACNAE W. 1954. On some eolidacean nudibranchiate molluscs from South Africa. Ann Natal Mus 13(1): 1-50.

MARONE EAND CAMARGO R. 1994. Marés meteorológicas no litoral do Estado do Paraná: o evento de 18 de agosto de 1993. Nerítica 8(1/2): 73-85.

MCDONALD GR. 2014. List of the worldwide food habits of nudibranchs. Available online at http://escholarship.org/ uc/item/0g75h1q3, accessed 20 March 2017.

NARANJO S, CARBALLO JL AND GARCÍA-GÓMEZ JC. 1998. Towards a knowledge of marine boundaries using ascidians as indicators: characterizing transition zones for species distribution along Atlantic-Mediterranean shores. Biol J Linn Soc 64(2): 151-177.

ORTEGA L AND MARTÍNEZ A. 2007. Multiannual and seasonal variability of water masses and fronts over the Uruguayan shelf. J Coast Res 23(3): 618-629.

OTTUSO PT. 2009. Aquatic antagonists: indirect nematocyst envenomation and acute allergic contact dermatitis due to nudibranchs. Cutis 83(5): 237-239.

PADULA V, BAHIA J, CORREIA MD AND SOVIERZOSKI HH. 2012. New records of opistobranchs (Mollusca: Gastropoda) from Alagoas, Northeastern Brazil. Mar Biodiv Rec 5(e57): 1-11.

RIOS EC. 1975. Brazilian Marine Mollusk Iconography. Rio Grande: Museu Oceanográfico da FURG, p. 180.

RIOS EC. 2009. Compendium of Brazilian Sea Shells, 2nd ed., Porto Alegre: Evangraf, p. 436. 
ROSS RM AND QUETIN LB. 1990. Mating behavior and spawning in two neustonic nudibranchs in the family Glaucidae. Amer Malacol Bull 8(1): 61-66.

SCARABINO F. 2004. Lista sistemática de los Gastropoda marinos y estuarinos vivientes de Uruguay. Com Soc Malac Uruguay 8(84/85-86/87): 305-346.

SEGOVIA J AND LÓPEZ G. 2015. Registro de Glaucus atlanticus en la costa de El Salvador, Pacífico de Centroamérica. Rev Mex Biodiv 86(4): 1089-1090.

SRINIVASULU B, SRINIVASULU C AND KUMAR GC. 2012. First record of the blue sea slug (Glaucus atlanticus) from Andhra Pradesh - India. Taprobanica J Asian Biodiv 4(1): 52-53.

THOMPSON TE AND BENNETT I. 1969. Physalia nematocysts: utilized by mollusks for defense. Science 166: 1532-1533.

THOMPSON TE AND BENNETT I. 1970. Observations on Australian Glaucidae (Mollusca: Opisthobranchia). Zool J Linn Soc 49(3): 187-197.
TIBBALLS J. 2006. Australian venomous jellyfish, envenomation syndromes, toxins and therapy. Toxicon 48(7): 830-859.

VALDÉS Á AND CAMPILLO OA. 2004. Systematics of pelagic aeolid nudibranchs of the family Glaucidae (Mollusca, Gastropoda). Bull Mar Sci 75(3): 381-389.

VANNUCCI M. 1939. Sobre uma lesma planctônica do litoral de Guarujá (Glaucus atlanticus Forst.). Bol Biol 4(3): 415422.

WÄGELE H AND KLUSSMANN-KOLB A. 2005. Opisthobranchia (Mollusca, Gastropoda) - more than just slimy slugs. Shell reduction and its implications on defense and foraging. Front Zool 2(3): 1-18.

WILLIAMSON JA, FENNER PJ, BURNETT JW AND RIFKIN JF. 1996. Venomous and poisonous marine animals: a medical and biological handbook, 4th ed., Sydney: University of New South Wales Press, 504 p. 